\title{
PENGARUH BI RATE DAN NILAI TUKAR RUPIAH-USD TERHADAP INVESTASI LQ45 DI BURSA EFEK INDONESIA TAHUN 2009-2015
}

\author{
Albertus Saptoprijono \\ STIE Unisadhuguna Jakarta, Indonesia \\ Email: albertus.saptoprijono@gmail.com
}

\begin{abstract}
Abstrak
Pendahuluan : Pasar modal yang ada di Indonesia merupakan pasar yang sedang berkembang, yang dalam perkembangannya sangat rentan terhadap kondisi makroekonomi secara umum. Pasar modal adalah "Tempat terjadinya transaksi aset keuangan jangka panjang atau long-term financial assets.

Tujuan : Tujuan penelitian ini untuk nilai tukar Rupiah dalam Dolar AS terhadap harga saham LQ45 di Bursa Efek Indonesia baik sebagian atau bersamaan dengan batasan waktu pada periode tahun 2009 hingga 2015.

Metode : dalam penelitian ini bersifat deskriptif kuantitatif, yaitu metode penelitian yang dilakukan dengan menjelaskan terlebih dahulu kondisi objek penelitian atau perusahaan yang diteliti berdasarkan fakta dan data yang tersedia untuk fakta. Untuk menguji hipotesis metode yang berlaku adalah regresi linier berganda menggunakan program Paket Statistik untuk Ilmu Sosial (SPSS) versi 24 dengan metode Enter. Teknik yang digunakan dalam penelitian ini menggunakan teknik purpose sampling di mana terdapat 20 (dua puluh) perusahaan yang masuk dan terdaftar selama 14 tahun (empat belas) dalam indeks LQ45 Bursa Efek Indonesia.

Hasil : Hasilnya menunjukkan bahwa data telah bertemu secara klasik seperti data distribusi normal, tidak ada multikolinearitas, tidak ada heteroscedasticity, dan tidak ada autokorelasi.

Kesimpulan : hasil analisis regresi linier dapat suku bunga variabel parsial dan simultan Bank Indonesia dan Nilai Tukar Rupiah dalam Dolar AS tidak mempengaruhi harga saham LQ45. Koofesien yang menentukan harga sahamLQ45 berarti sebesar 0,2\% yang berarti bahwa suku bunga Bank Indonesia dan Nilai Tukar Rupiah terhadap Dolar AS memberikan Pengaruh pada Harga Saham LQ45, sedangkan selisihnya adalah 99,8\% oleh variabel lain yang tidak ada dalam penelitian.
\end{abstract}

Kata kunci : Suku Bunga Bank Indonesia; Nilai Tukar Rupiah dalam Dolar Amerika Serikat; dan Harga Saham LQ45

\section{Abstract}

Introduction: The capital market in Indonesia is an emerging market, which in its development is very vulnerable to macroeconomic conditions in general. Capital market is "The place of long-term financial asset transactions or long-term financial assets.

Objective: The purpose of this study is for the exchange rate of Rupiah in US Dollars against the share price of LQ45 on the Indonesia Stock Exchange either partially or simultaneously with the time limit in the period 2009 to 2015.

Method: in this research is quantitative descriptive, which is a research method that is done by explaining in advance the condition of the research object or company studied based on facts and data available for facts. To test the hypothesis 
the prevailing method is multiple linear regression using the Statistical Package for Social Sciences (SPSS) version 24 program with the Enter method. The technique used in this study uses purpose sampling techniques where there are 20 (twenty) companies entered and registered for 14 years (fourteen) in the Indonesia Stock Exchange's LQ45 index.

Results: The results showed that the data had met classically like normal distribution data, no multicollinearity, no heteroscedasticity, and no autocorrelation.

Conclusion: the results of linear regression analysis can be bank Indonesia's partial and simultaneous variable interest rates and the Rupiah Exchange Rate in US Dollars does not affect the share price of LQ45. Koofesien who determines the stock-LQ45 price means $0.2 \%$ which means that Bank Indonesia's interest rate and the Rupiah exchange rate against the US Dollar exert an influence on the LQ45 Share Price, while the difference is $99.8 \%$ by other variables that were not in the study.

Keywords: Bank Indonesia Interest Rates; Rupiah Exchange Rate in US Dollars; and LQ45 Share Price.

\section{Pendahuluan}

Sejak terjadinya krisis moneter pada tahun 1997 dunia bisnis terutama dalam sektor perusahaan telah mengalami pasang surut (Fahmi, 2017). Perkembangan dalam sektor perusahaan juga diikuti kebutuhan dana yang besar sehingga perusahaanperusahaan harus mencari sumber dana guna melakukan operasionalnya (Lestari, 2010). Kebutuhan sumber dana tersebut dapat dipenuhi dengan melakukan go public atau menjual sahamnya kepada masyarakat melalui pasar modal (Muklis, 2016). Alternatif ini merupakan alternatif yang lebih mudah dan murah jika dibandingkan sumber pendanaan lain, misalnya melakukan peminjaman atau utang pada pihak lain.

Pasar modal merupakan tempat bertemunya para pemodal dan pencari modal. Menurut (Faozan, 2013) Pasar modal yang ada di Indonesia merupakan pasar yang sedang berkembang, yang dalam perkembangannya sangat rentan terhadap kondisi makroekonomi secara umum. Pasar modal adalah "Tempat terjadinya transaksi aset keuangan jangka panjang atau long-term financial assets. Pengertian klasik pasar modal adalah suatu sarana dengan mana surat berharga-surat berharga yang berjangka panjang diperjualbelikan (Pebrianti, 2011)" Dalam pengertian ini pasar modal memiliki tujuan normatif mencapai keuntungan yang optimal (Juliati, 2015). Namun demikian menurut (Muklis, 2016) sebagai salah satu pelaku ekonomi nasional pasar modal memiliki fungsi intermediasi yaitu menjembatani antara pihak yang membutuhkan modal dengan pihak yang kelebihan modal. Meski demikian, kemampuan pasar modal di Indonesia untuk berkembang sehingga dapat meningkatkan intermediasi dana dengan lebih efisien perlu didukung oleh lembaga keuangan dibawah pasar modal, yaitu perusahaan sekuritas, dan reksadana yang andal dan efisien, serta manajemen bursa yang efisien dengan dukungan otoritas pasar modal yang kondusif terhadap perkembangan pasar modal (Haryuningputri \& Widyarti, 2012).

Risiko tingkat suku bunga dan nilai tukar mata uang merupakan dua faktor ekonomi dan keuangan yang secara signifikan mempengaruhi nilai saham. Tingkat suku bunga secara tidak langsung mempengaruhi nilai dari harga saham (Mardiyati \& Rosalina, 2013). Kenaikan suku bunga berpengaruh negatif terhadap nilai aset dari peningkatan tingkat pengembalian (return) yang diperlukan. Selain itu, tingkat suku 
bunga yang tinggi menyebabkan investor mengubah struktur / investasi dari pasar modal menuju pasar surat-surat berharga yang merupakan pendapatan berjangka tetap (fixed-term income), seperti obligasi pemerintah (Harsono, 2018). Sebaliknya, penurunan tingkat suku bunga menyebabkan peningkatan nilai pada saat sekarang dari dividen masa depan. Tingkat suku bunga dianggap sebagai salah satu penentu paling signifikan dari harga saham (Pratama, 2011).

Bunga bank dapat diartikan sebagai "Balas jasa yang diberikan oleh bank berdasarkan prinsil konvensional kepada nasabah yang membeli atau menjual produknya. Bunga bagi bank juga dapat diartikan sebagai harga yang harus dibayar kepada nasabah (yang memiliki simpanan) dan harga yang harus dibayar oleh nasabah kepada bank (nasabah yang memperoleh pinjaman) (Romdhoni, Tho'in, \& Wahyudi, 2012)." Faktor-faktor utama yang memengaruhi besar kecilnya penetapan suku bunga secara garis besar yaitu, kebutuhan dana, persaingan, kebijaksanaan pemerintah, target laba yang diinginkan, jangka waktu, kualitas jaminan, reputasi perusahaan, produk yang kompetitif, hubungan baik, dan jaminan pihak ketiga (Semaun, 2015).

Adapun pertanyaan penelitian yang telah disusun (1). Apakah ada pengaruh parsial antara perubahan tingkat suku bunga bank Indonesia terhadap harga saham LQ45 di Bursa Efek Indonesia Tahun 2009-2015? (2) Apakah ada pengaruh parsial antara perubahan nilai tukar rupiah pada US Dollar terhadap harga saham LQ45 di Bursa Efek Indonesia Tahun 2009-2015? (3) Apakah ada pengaruh simultan antara perubahan tingkat suku bunga bank Indonesia dan nilai tukar rupiah pada US Dollar terhadap harga saham LQ45 di Bursa Efek Indonesia Tahun 2009-2015?

\section{Metode Penelitian}

Metode penelitian berupa kuantitatif, (data penelitian berupa angka dari beberapa sumber) (Suliyanto \& MM, 2017). Teknik Pengumpulan data bersumber dari data sekunder. Analisis data dengan menggunakan alat bantu program Statistical Package for the Social Science (SPSS) (Ghozali, 2018).

Menurut Sugiyono (2011:215) dalam penelitian kuantitatif, populasi diartikan sebagai wilayah generalisasi yang terdiri atas objek atau subjek yang mempunyai kualitas dan karakteristik tertentu yang ditetapkan oleh peneliti untuk dipelajari dan kemudian ditarik kesimpulannya. Populasi yang digunakan dalam penelitian ini adalah seluruh perusahaan yang sahamnya tergabung dalam indeks LQ45 di BEI selama periode penelitian 2009 sampai dengan 2015. Dan Sampel (Sugiyono, 2017) dalam penelitian kuantitatif, sampel adalah sebagian dari populasi itu sendiri. Sampel pada penelitian ini adalah perusahaan yang sahamnya tergabung dalam indeks LQ45 di BEI yang dipilih dengan metode purposive sampling (teknik pengambilan sampel secara sengaja atau peneliti menentukan sendiri sampel yang diambil karena ada pertimbangan tertentu). Kriteria pemilihan sampel penelitian yaitu perusahaan yang aktif tercatat / terdaftar sebanyak empat belas (14) kali secara berturut-turut di Indeks LQ45 selama periode penelitian 2009-2015

\section{Hasil dan Pembahasan}

\section{Hasil Analisis Deskriptif}

- Suku Bunga Bank Indonesia

MINIMUM : $5,77 \%$

MAKSIMUM : $7,54 \%$

- Nilai Tukar Rp-USD

TERENDAH : Rp 8.779,49 
TERTINGGI : Rp 13.391,97

- Harga Saham-saham LQ45

TERENDAH : Rp 260 (PT. KALBE FARMA, Tbk) 2009

\section{Hasil Uji Hipotesis}

\section{Tabel 1}

\section{Hasil Uji Parsial (Uji - t) Tingkat Suku Bunga BI $\left(\mathbf{X}_{1}\right)$} Coefficients $^{\mathrm{a}}$

\begin{tabular}{lccccc}
\hline & \multicolumn{2}{c}{ Unstandardized } & \multicolumn{2}{c}{$\begin{array}{c}\text { Standardized } \\
\text { Coefficients }\end{array}$} & \multicolumn{2}{c}{ Coefficients } & \multirow{2}{*}{$\mathrm{t}$} & \multirow{2}{*}{ Sig. } \\
\cline { 2 - 5 } Model & $\mathrm{B}$ & Std. Error & Beta & & \\
\hline 1 (Constant $)$ & 14491,585 & 9307,289 & & 1,557 &, 122 \\
\hline Suku Bunga BI & $-670,148$ & 1365,207 &,- 042 &,- 491 &, 624 \\
\hline
\end{tabular}

a. Uji Parsial (Uji t) Suku Bunga BI

$\mathrm{t}$ hitung : -0,491 $\mathrm{t}$ tabel : 1,97730 ( $\mathrm{t}$ hitung $<\mathrm{t}$ tabel) dan dengan tingkat signifikan variabel suku bunga BI sebesar : 0,624>0,05 dari taraf signifikan. Maka artinya H0 diterima dan Ha ditolak (secara parsial suku bunga BI tidak berpengaruh terhadap harga saham-saham LQ45).

Tabel 2

Hasil Uji Parsial (Uji t) Nilai Tukar Rupiah pada US Dollar (X2) Coefficients $^{\mathbf{a}}$

\begin{tabular}{|c|c|c|c|c|c|}
\hline \multirow[b]{2}{*}{ Model } & \multicolumn{2}{|c|}{$\begin{array}{c}\text { Unstandardized } \\
\text { Coefficients }\end{array}$} & \multirow{2}{*}{$\begin{array}{c}\begin{array}{c}\text { Standardized } \\
\text { Coefficients }\end{array} \\
\text { Beta } \\
\end{array}$} & \multirow[t]{2}{*}{$\mathrm{t}$} & \multirow[t]{2}{*}{ Sig. } \\
\hline & $\mathrm{B}$ & Std. Error & & & \\
\hline 1 (Constant) & 12074,524 & 5612,151 & & 2,151 & 033 \\
\hline Nilai Tukar Rupiah &,- 204 & .530 &,- 033 & -384 & 701 \\
\hline
\end{tabular}

b. Uji Parsial (Uji t) Nilai Tukar Rp-USD

$\mathrm{t}$ hitung : $-0,384 \mathrm{t}$ tabel : 1,97730 ( $\mathrm{t}$ hitung $<\mathrm{t}$ tabel) dan dengan tingkat signifikan variabel suku bunga BI sebesar : 0,701 >0,05 dari taraf signifikan. Maka artinya $\mathrm{HO}$ diterima dan Ha ditolak (secara parsial suku bunga BI tidak berpengaruh terhadap harga saham-saham LQ45).

3. Uji Asumsi Klasik

Tabel 3

Hasil Uji Normalitas

One-Sample Kolmogorov-Smirnov Test 4

\begin{tabular}{lll}
\hline & & Unstandardized Residual \\
\hline $\mathrm{N}$ & $140^{\mathrm{c}}$ \\
$\begin{array}{l}\text { Exponential } \quad \text { Mean } \\
\text { parameter. }\end{array}$ & 10548,0040700 \\
Most Extreme Absolute &, 135 \\
Differences $\quad$ Positive &, 074 \\
\multicolumn{2}{l}{ Kolmogorov-Smirnov Z } &,- 135 \\
\multicolumn{2}{l}{ Kolmative } &, 954
\end{tabular}


a. Uji Normalitas

Nilai Kolmogorov-Smirnov : 0,954

Nilai Asymp. Sig. (2-tailed) : 0,323

Karena nilai signifikansi lebih dari $0,05(0,323>0,05)$ maka nilai residual terdistribusi dengan NORMAL

\section{Uji Korelasi}

a. Koefisien korelasi antara Suku Bunga BI dengan Harga Saham-saham LQ45 : 0,042 (LEMAH dengan hubungan NEGATIF) Dan tidak terjadi hubungan yang signifikan antara suku bunga BI dengan harga saham LQ45 karena Sig. (2-tailed) sebesar 0,624 $(0,624>0,05)$

b. Koefisien korelasi antara Nilai Tukar RP-USD dengan Harga Saham-saham LQ45 : -0,033 (LEMAH dengan hubungan NEGATIF) Dan tidak terjadi hubungan yang signifikan antara nilai tukar RP-USD dengan harga saham LQ45 karena Sig. (2-tailed) sebesar 0,701 (0,701 > 0,05).

\section{Tabel 4}

Hasil Uji Korelasi

Correlations

\begin{tabular}{llrrr}
\hline & & Suku Bunga BI & $\begin{array}{r}\text { Nilai Tukar } \\
\text { Rupiah }\end{array}$ & $\begin{array}{r}\text { Harga Saham } \\
\text { Lq45 }\end{array}$ \\
\hline Suku Bunga BI & Pearson Correlation & 1 &, $786^{* *}$ &,- 042 \\
\cline { 2 - 5 } & Sig. (2-tailed) & 140 &, 000 &, 624 \\
\cline { 2 - 5 } & $\mathrm{N}$ &, $786^{* *}$ & 140 & 140 \\
\hline $\begin{array}{l}\text { Nilai Tukar } \\
\text { Rupiah }\end{array}$ & Pearson Correlation &, 000 & &,- 033 \\
\cline { 2 - 5 } & Sig. (2-tailed) & 140 & 140 &, 701 \\
\cline { 2 - 5 } & $\mathrm{N}$ &,- 042 &,- 033 & 140 \\
\hline \multirow{2}{*}{$\begin{array}{l}\text { Harga Saham } \\
\text { Lq45 }\end{array}$} & Pearson Correlation &, 624 &, 701 & 1 \\
\cline { 2 - 5 } & Sig. (2-tailed) & 140 & 140 & 140 \\
\cline { 2 - 5 } & $\mathrm{N}$ & & &
\end{tabular}

\section{Analisis Koofisen Determinasi}

Tabel 5

Hasil Uji Koefisien Determinasi

\begin{tabular}{lclll}
\hline Model & R & R Square & Adjusted R Square & Std. Error of the Estimate \\
\hline 1 &, $042^{\mathrm{a}}$ &, 002 &,- 013 & 9653,79477 \\
\hline
\end{tabular}

Penelitian ini menunjukkan bahwa nilai Koefisien Determinasi ( $R$ Square) : 0,002 atau 0,2\% Artinya bahwa suku bunga BI dan nilai tukar RP-USD memberikan pengaruh terhadap harga saham-saham LQ45 sebesar 0,2\%, sedangkan sisanya 99,8\% dipengaruhi oleh variabel lain yang tidak digunakan dalam penelitian. 


\section{Analisis Regresi Linier Berganda}

\begin{tabular}{|c|c|c|c|c|c|c|c|}
\hline & & & asil Uji Re & $\begin{array}{c}\text { Tabel } 6 \\
\text { egresi Linear } \\
\text { Coefficients }^{\mathrm{a}}\end{array}$ & rgand & & \\
\hline & & $\begin{array}{r}\text { Unstand } \\
\text { Coeffi } \\
\end{array}$ & $\begin{array}{l}\text { ardized } \\
\text { ients }\end{array}$ & $\begin{array}{c}\text { Standardized } \\
\text { Coefficients } \\
\end{array}$ & & & Collinearity \\
\hline & & & Std. & & & & Statistics \\
\hline & Model & B & Error & Beta & $\mathbf{T}$ & Sig. & Tolerance $\quad$ VIF \\
\hline 1 & (Constant) & 14498,756 & 9759,937 & & 1,486 &, 140 & \\
\hline & $\begin{array}{l}\text { Suku Bunga } \\
\text { BI }\end{array}$ & $-674,572$ & 2218,285 &,- 042 &,- 304 & ,762 & ,382 2,621 \\
\hline & $\begin{array}{l}\text { Nilai Tukar } \\
\text { Rupiah }\end{array}$ &, 002 &, 861 &, 000 & ,003 & ,998 & ,382 2,621 \\
\hline
\end{tabular}

$$
\mathrm{Y}=14498.756-674.572 \mathrm{X} 10.002
$$

a. Koefisien regresi suku bunga BI bernilai -674,572 (Setiap kali terjadi peningkatan sebesar 1 kali pada tingkat suku bunga BI, maka akan terjadi penurunan pada harga saham LQ45 sebesar 674,572 secara negatif berarti suku bunga BI berjalan berlawanan dengan harga saham-saham LQ45).

b. Koefisien regresi nilai tukar rupiah pada US Dollar bernilai 0,002 (Setiap kali terjadi peningkatan sebesar 1 kali pada nilai tukar rupiah pada US Dollar, maka akan terjadi peningkatan pada harga saham LQ45 sebesar 0,002 secara positif berarti nilai tukar rupiah pada US Dollar berjalan searah dengan harga sahamsaham LQ45).

\section{Kesimpulan}

Berdasarkan hasil penelitian maka diperoleh kesimpulan bahwa variabel suku bunga Bank Indonesia mempunyai pengaruh negatif dan tidak signifikan terhadap Harga Saham-saham LQ45 di Bursa Efek Indonesia selama periode 2009 sampai dengan 2015 karena hasil dari regresi sederhana sebesar $\mathrm{Y}=14491,585-670,148 \mathrm{X}_{1}$ yang berarti jika Suku Bunga Bank Indonesia bernilai 0 (nol), maka nilai Harga Sahamsaham LQ45 sebesar 14491,585. Dan jika setiap kali terjadi peningkatan sebesar 1 kali pada Suku Bunga Bank Indonesia, maka akan terjadi penurunan pada Harga Sahamsaham LQ45 sebesar 670,148. Dan untuk hasil dari nilai signifikansi dapat dilihat dari nilai $t_{\text {hitung }}$ lebih kecil dari $t_{\text {tabel }}(-0,491<1,97743)$ dan dengan tingkat signifikan variabel Suku Bunga Bank Indonesia sebesar 0,624 lebih besar dari taraf signifikan 0,05 $(0,624<0,05)$.

Variabel Nilai Tukar Rupiah pada US Dollar mempunyai pengaruh negatif dan tidak signifikan terhadap Harga Saham-saham LQ45 di Bursa Efek Indonesia selama periode 2009 sampai dengan 2015 karena hasil dari regresi sederhana sebesar Y = 12074,524 - 0,204 X 2 yang berarti jika Nilai Tukar Rupiah Pada US Dollar bernilai 0 (nol), maka nilai Harga Saham-saham LQ45 sebesar 12074,524. Dan jika setiap kali terjadi peningkatan sebesar 1 kali pada Nilai Tukar Rupiah, maka akan terjadi penurunan pada Harga Saham-saham LQ45 sebesar 0,204. Dan untuk hasil dari nilai signifikansi dapat dilihat dari nilai $t_{\text {hitung }}$ lebih kecil dari $t_{\text {tabel }}(-0,384<1,97743)$, dan 


\section{Albertus Saptoprijono}

dengan tingkat signifikan variabel Nilai Tukar Rupiah pada US Dollar sebesar 0,701 lebih besar dari taraf signifikan 0,05 $(0,701>0,05)$.

Disimpulkan bahwa variabel Suku Bunga Bank Indonesia dan Nilai Tukar Rupiah pada US Dollar secara simultan (bersama-sama) tidak mempunyai pengaruh yang signifikan terhadap Harga Saham-saham LQ45 di Bursa Efek Indonesia selama periode 2009 sampai dengan 2015. Hal ini dibuktikan oleh hasil dari uji persamaan regresi linier berganda, yaitu:

$\mathrm{Y}=14498,756-674,572 \mathrm{X}_{1}-0,002 \mathrm{X}_{2}$ dan uji $\mathrm{F}=\mathrm{F}_{\text {hitung }}<\mathrm{F}_{\text {tabel }}(0,120<3,06)$ dengan tingkat signifikan 0,887 lebih besar dari taraf signifikan sebesar $0,05(0,887>$ $0,05)$. 


\section{DAFTAR PUSTAKA}

Fahmi, Irham. (2017). Analisis laporan keuangan.

Faozan, Akhmad. (2013). Konsep pasar modal syariah. Muqtasid: Jurnal Ekonomi Dan Perbankan Syariah, 4(2), 287-310.

Ghozali, Imam. (2018). Aplikasi analisis multivariate dengan program IBM SPSS 25.

Harsono, Ardelia Rezeki. (2018). Pengaruh Inflasi, Suku Bunga, dan Nilai Tukar Rupiah Terhadap Indeks Harga Saham Gabungan (Studi pada Bursa Efek Indonesia Periode 2013-2017). Universitas Brawijaya.

Haryuningputri, Meilinda, \& Widyarti, Endang Tri. (2012). Pengaruh rasio profitabilitas dan eva terhadap harga saham pada sektor industri manufaktur di bei tahun 20072010. Diponegoro Journal of Management, 1(4), 67-79.

Juliati, Yenni Samri. (2015). Peranan Pasar Modal Dalam Perekonomian Negara. HUMAN FALAH: Jurnal Ekonomi Dan Bisnis Islam, 2(1), 95-112.

Lestari, Anita Dwi. (2010). Pengaruh struktur aktiva, pertumbuhan, dan likuiditas terhadap struktur modal perusahaan. Jurnal Riset Akuntansi Dan Keuangan, 6(2), $155-165$.

Mardiyati, Umi, \& Rosalina, Ayi. (2013). Analisis pengaruh nilai tukar, tingkat suku bunga dan inflasi terhadap indeks harga saham studi kasus pada perusahaan properti yang terdaftar di bursa efek Indonesia. JRMSI-Jurnal Riset Manajemen Sains Indonesia, 4(1), 1-15.

Muklis, Faiza. (2016). Perkembangan dan tantangan pasar modal Indonesia. Al-Masraf: Jurnal Lembaga Keuangan Dan Perbankan, 1(1), 65-76.

Pebrianti, Prima. (2011). Pengaruh Arus Kas Operasi Dan Laba Operasi Terhadap Return Saham (Pada Perusahaan Manufaktur yang Terdaftar Di BEI).

Pratama, Muhammad Anditia Putra. (2011). Analisis Pengaruh Suku Bunga dan Nilai Tukar Terhadap Volatilitas dan Return pada Indeks Saham Sektoral di Bursa Efek Indonesia.

Romdhoni, Abdul Haris, Tho'in, Muhammad, \& Wahyudi, Agung. (2012). Sistem Ekonomi Perbankan Berlandaskan Bunga (Analisis Perdebatan Bunga Bank Termasuk Riba Atau Tidak). Jurnal Akuntansi Dan Pajak, 13(01).

Semaun, Syahriyah. (2015). Analisis Perbandingan Penentuan Profit Margin pada Bank Syariah dan Bunga pada Bank Konvensional. DIKTUM: Jurnal Syariah Dan Hukum, 13(2), 164-173.

Sugiyono. (2017). Metode Penelitian Kuantitatif, Kualitatif, dan R\&D. Bandung: Alfabeta.

Suliyanto, S. E., \& MM, Suliyanto. (2017). Metode Penelitian Kuantitatif. 